\title{
LUMBOSACRAL TRANSITIONAL ANATOMY TYPES AND DISC DEGENERATIVE CHANGES
}

\author{
Chabukovska Radulovska Jasminka, ${ }^{1}$ Matveeva Niki, ${ }^{2}$ Poposka Anastasika ${ }^{3}$ \\ ${ }^{1}$ University Clinic of Surgery "St. Naum Ohridski” Skopje, R Macedonia \\ ${ }^{2}$ University "St Cyril and Methodius", Medical Faculty, Institute of Anatomy, Skopje, R Macedonia \\ ${ }^{3}$ University Clinic of Orthopaedics Skopje, R Macedonia
}

Primljen/Received 02. 04. 2014. god.

Abstract: Background and purpose: The relationship between presence of lumbosacral transitional vertebra (LSTV) and disc degenerative changes is unclear. The aim of the study was to examine the relation between different types of LSTV and disc degenerative changes at the transitional and the adjacent cephalad segment.

Material and methods: Sixty-three patients (mean age $51.48 \pm 13.51$ ) out of 200 adults with low back pain who performed MRI examination of the lumbosacral spine, classified as positive for LSTV, were included in the study. Annular tears, disc degeneration according to Phirmann classification and disc herniations were evaluated and graded at transitional and adjacent cephalad level.

Results: The severity of disc degeneration at the transitional level and the adjacent level correlated with the types of LSTV. Severe disc degenerative changes were most frequent in articulated connection LSTV types and in combined LSTV type at the transitional level and in osseus connection LSTV types at the adjacent cephalad level. These changes were more frequent in unilateral articulated connection LSTV subtype (64\% vs $54 \%$ ); and in unilateral osseus connection LSTV subtype ( $25 \%$ vs no patients) at transitional level, and in bilateral osseus connection LSTV subtype $(100 \%$ vs $50 \%)$ at the level above. High prevalence of disc herniations was observed in articulated connection LSTV types as well as in unilateral osseus connection LSTV subtype at transitional and the adjacent cephalad level. At the transitional level higher prevalence of disc herniations was characteristic for unilateral articulated connection LSTV subtype (46\%vs $41 \%$ ) and for unilateral osseus connection LSTV subtype (50\% vs no patients). At the adjacent level higher prevalence of disc herniations was observed in bilateral articulated
Prihvaćen/Accepted 21. 05. 2014. god.

connection LSTV subtype (38\% vs $27 \%$ ) and in bilateral osseus connection LSTV subtype (50\% vs $25 \%$ ).

Conclusions: The compact osseus connection (osseus bridging vs articular bridging) of the lumbosacral transitional vertebra with the sacrum protects the disc at the transitional level and produces greater stress to adjacent cephalad segment. Bilateral osseus bridging seems to be most protective to the disc at the transitional level, but this type of LSTV produces great stress to the adjacent cephalad level.

Key words: lumbosacral anomalies; lumbosacral transitional vertebra; disc degeneration.

\section{INTRODUCTION}

Lumbosacral transitional vertebra (LSTV) are vertebra lying at the juncture of lumbar and sacral spinal segments that exhibit characteristics of the neighboring vertebral class. These characteristics usually regard to the shape and fusion patterns of their transverse processes. Sacralization of L5 occurs when enlarged transverse process (TP) form pseudoarthrosis or fuse unilaterally or bilaterally with the sacrum. Lumbarization of S1 occurs when the transverse process of S1 fails to fuse with the remainder of sacrum. The antero-posterior x-ray of the lumbar spine is the reference standard method to detect LSTV. Coronal and axial imagesin MRI studies on the lumbar spine highlight the transitional lumbosacral anatomy and depict the pseudoarthrosis or osseus fusion of the last lumbar vertebra with the sacrum. The most important implication for radiologists is the misnumbering of transitional vertebra, especially when important findings exist at the transitional level, at theadjacent level, or when spinal surgery is contemplated. The incidence of this developmental spinal anomaly is between 4 and $30 \%$ in 
general population (1). Controversial opinions exist regarding to the clinical significance of this entity $(2,3)$. Some authors reported that a lumbosacral transitional vertebra is protective for disc degeneration at the transitional segment, but prone to greater disc degeneration at the level above $(4,5)$. Other investigators reported earlier occurrence and more severe degeneration in subjects with LSTV $(4,6)$. It has been widely accepted that LSTV alter the biomechanics of the spine and contribute to low back pain $(7,8,9)$.

The aim of the study was to investigate the occurrence of LSTV in back pain population and to examine the relation between different types of LSTV and disc degenerative changes at transitional and adjacent cephalad segment. These issues can help in understanding the natural history of lumbar spine degeneration in the presence of LSTV, which is important for surgeons to make a decision and select appropriate fusion levels or disc replacement levels.

\section{MATERIAL AND METHODS}

MRI images of the lumbar spine performed in adults with low back pain over a period of six months (from September 2012 to February2013) were analyzed. After institutional review and board approval, out of 200 patients with low back pain (19-83 years old), who underwent MR imaging of the lumbosacral spine, 63 were retrospectively selected and included in the study. Patients with kyphoscoliosis, history of previous spine surgery, spinal fracture, other congenital spinal anomalies, tumor or infection were excluded from the study. MR imaging examination of the lumbosacral spine was preformed with 1,5 T MR unit (Signa HDI ) with a spinal surface coil. The imaging protocol consisted of a sagittal T1-weighted fast spin-echo sequence (FSE) (repetition time msec/echo time msec, 800/14; section thickness, $4 \mathrm{~mm}$; field of view, $360 \mathrm{x}$ $360 \mathrm{~mm}$; matrix, $448 \times 224$ ), sagittal T2-weighted turbo spin-echo sequence (3520/102; section thickness, 4 $\mathrm{mm}$; intersection gap, $10 \mathrm{~mm}$; echo train length of 24), coronal T2-weighted fast spin-echo sequence (FSE) and a transverse T2-weighted fast recovery fast spin-echo (FRFSE) sequence at one or multiple levels $(4,660 / 120$; section thickness, $4 \mathrm{~mm}$; intersection gap, $0.6 \mathrm{~mm}$; echo train length of 27; field of view, $200 \times 200 \mathrm{~mm}$; matrix 320 x 256). Diagnostic imaging was performed by a diagnostic radiologist who was blinded to the original reports of the MRI studies in order to evaluate subjects with LSTV.

Subjects with dysplastic transverse process (height equal or greater than $19 \mathrm{~mm}$ ), unilateral or bilateral, without articulated or osseus fusion between the process and sacrum were not included in the study.The patients with LSTV were divided in three groups based on the Castellvi classification - type II, articulated connection between TP and sacrum $(\mathrm{N}=46)$, type III, osseus connection between TP and sacrum $(\mathrm{N}=8)$, type IV, both osseus and articulated connection between TP and sacrum $(\mathrm{N}=9)$. The two types of LSTV (II and III) were divided in two subtypes based on the unilateral or bilateral presence of articulated or osseus connection. Disc degeneration was evaluated and graded using the Phirrmann classification system in the last two fully developed discs (10). Annular tears were also evaluated and the presence of disc herniations was notified and graded (1-protrusions, 2-extrusions).

Statistical analysis was performed using SPSS (version 20, Chicago, IL.USA). A chi square test was used for statistical comparison between groups and subgroups for categorical variables. Kruskal Wallis test was used to compare disc degeneration Phirmann grades and disc herniationsgrades between LSTV groups and subgroups. A p value less than 0.05 was considered statistically significant.

\section{RESULTS}

Out of two hundred subjects ( 85 men and 115 women), $63(31.5 \%)$ were classified as positive for transitional lumbosacral vertebra and included in the study. Their average age was 51.48 years (19-83). The gender distribution of LSTV positive subjects was 25 $(40 \%)$ men, and $38(60 \%)$ women. The evaluated types of transitional lumbosacral vertebra were unilateral enlarged TP with pseudoarthrosis categorized as IIA, in 24 (38.1\%) subjects, bilateral enlarged TP with pseudoarthrosis categorized as IIB, in 22 (34.9\%) subjects, enlarged TP with unilateral complete fusion with the sacrum categorized as IIIA, in $4(6.3 \%)$ subjects, bilateral enlarged TP with complete fusion also in $4(6.3 \%)$ subjects. Mixed type with pseudoarthrosis on one side and complete fusion on the other side was present in 9 $(14.3 \%)$ subjects. The most common anatomical variant was the Castellvi type IIA (38.1\%), followed by type IIB (34.9\%), type IV (14.3\%) and type IIIA (6.3\%) and IIIB (6.3\%). Sacralization was evaluated in 54 $(86 \%)$ patients and lumbarization in $9(14 \%)$ patients. Statistical significant difference for gender distribution by Castellvi classification groups was not observed (Table1).

\section{Disc degeneration}

At the transitional level among the LSTV groups disc degeneration was most frequent in patients with lumbosacral transitional vertebra type II (Phirmann grade 4 and 5 in $63.6 \%$ patients with LSTV type IIA 


\begin{tabular}{|l|c|c|c|}
\hline $\begin{array}{c}\text { Castellvi } \\
\text { type }\end{array}$ & N (\%) & Men & Women \\
\hline Type IIA & $24(38,1 \%)$ & $13(20,6 \%)$ & $11(17,5 \%)$ \\
\hline Type IIB & $22(34,9 \%)$ & $8(12,7 \%)$ & $14(22,2 \%)$ \\
\hline Type IIIA & $4(6,3 \%)$ & $/$ & $4(6,3 \%)$ \\
\hline Type IIIB & $4(6,3 \%)$ & $2(3,2 \%)$ & $2(3,2 \%)$ \\
\hline Type IV & $9(14,3 \%)$ & $2(3,2 \%)$ & $7(11,1 \%)$ \\
\hline Total & 63 & 25 & 38 \\
\hline
\end{tabular}

Table 1. Gender distribution by Castellvi classification groups

and $54.2 \%$ patients with LSTV type IIB) and in combined LSTV type (Phirmann grade 4 and 5 in 55.6\% patients with combined LSTV). Phirmann grade 1 and 2 was most frequent in patients with LSTV type IIIB ( $25 \%$ patients with LSTV type IIIB) (Figure 1). In patients with unilateral LSTV subtypes (A) of LSTV type II and III, Phirmann grade 4 and 5 was more frequent than in patients with bilateral LSTV subtypes (B) $(64 \%$ patients with LSTV type IIA vs 54\% patients with LSTV type IIB, $25 \%$ of patients with LSTV type IIIA vs no patients with LSTV type IIIB).

At the adjacent cephalad segment, lumbosacral transitional vertebra types with most frequent severe disc degenerative changes were LSTV type III and combined LSTV type. Phirmann grade 4 and 5 was most frequent in patients with LSTV type III and LSTV combined type (100\% patients type IIIB, 50\% patients type IIIA and $55.6 \%$ patients type combined LSTV) (Figure 2). Bilateral osseus connection LSTV subtype IIIB was characterized with absence of severe degenerative disc changes at the transitional level, and

Figure 1. Disc degeneration grades

(Phirmann grading) at the transitional segment in different types of lumbosacral transitional vertebra (LSTV Castellvi classification)

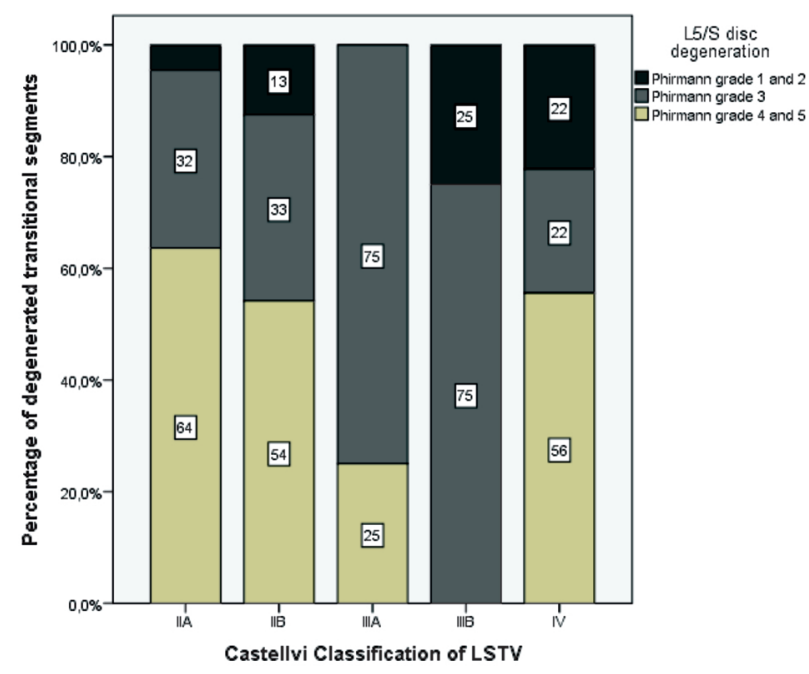

Figure 2. Disc degeneration grades (Phirmann grading) at the adjacent cephalad segment in different types of lumbosacral transitional vertebra (LSTV Castellvi classification)

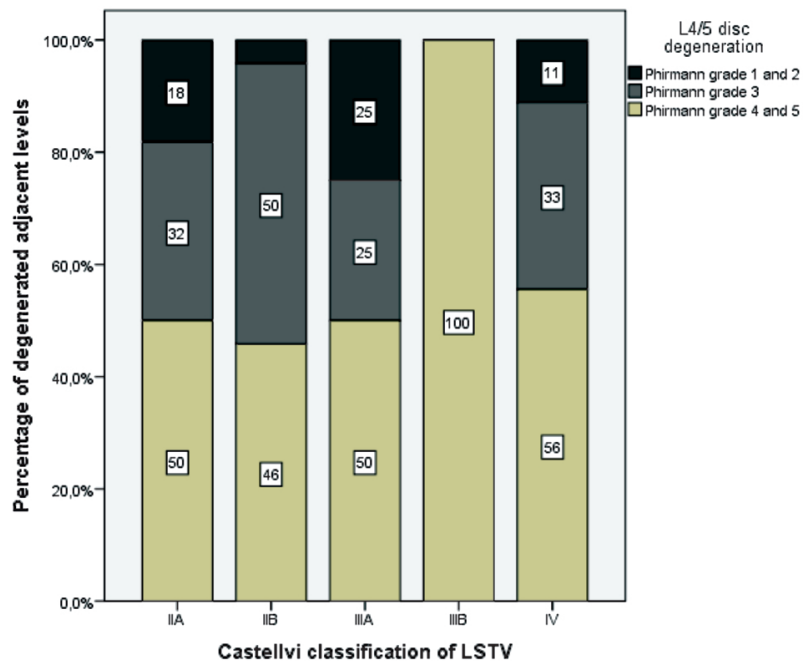

appearance of severe disc degeneration at the adjacent cephalad level. In general, there was no significant difference in disc degeneration between different groups and subgroups of LSTV at transitional and the adjacent cephalad level.

\section{Annular tears}

High prevalence of annular tears at the transitional level within the types of LSTV was observed in LSTV type III ( $25 \%$ patients with LSTV type IIIA demonstrated annular tears at the transitional level). Higher prevalence of annular tears at the transitional level, although not significant, was observed in patients with unilateral articulated or osseus fusion vs bilateral articulated or osseus fusion (23\% patients with unilateral LSTV type IIA vs $13 \%$ patients with LSTV type IIB, $25 \%$ patients with unilateral LSTV type IIIA vs no patients with bilateral LSTV type IIIB). Only 3 patients demonstrated annular tears at the cephalad adjacent level.

\section{Disc herniations}

Among the transitional lumbosacral vertebra subgroups the greatest number of disc herniations at the transitional level were found in lumbosacral transitional vertebra type II ( $46 \%$ disc herniations in patients with LSTV type IIA and $41 \%$ disc herniations in patients with LSTV type IIB) (Figure 3). Higher prevalence of disc herniations was characteristic for unilateral articulated connection LSTV subtype (46\% disc herniations for unilateral articulated connection LSTV subtype vs $41 \%$ disc herniations for bilateral articulated connection LSTV subtype) and for unilateral osseus connection LSTV subtype (50\% disc herniations for 
Figure 3. Disc herniations at the transitional segment in different types of lumbosacral transitional vertebra (LSTV Castellvi classification)

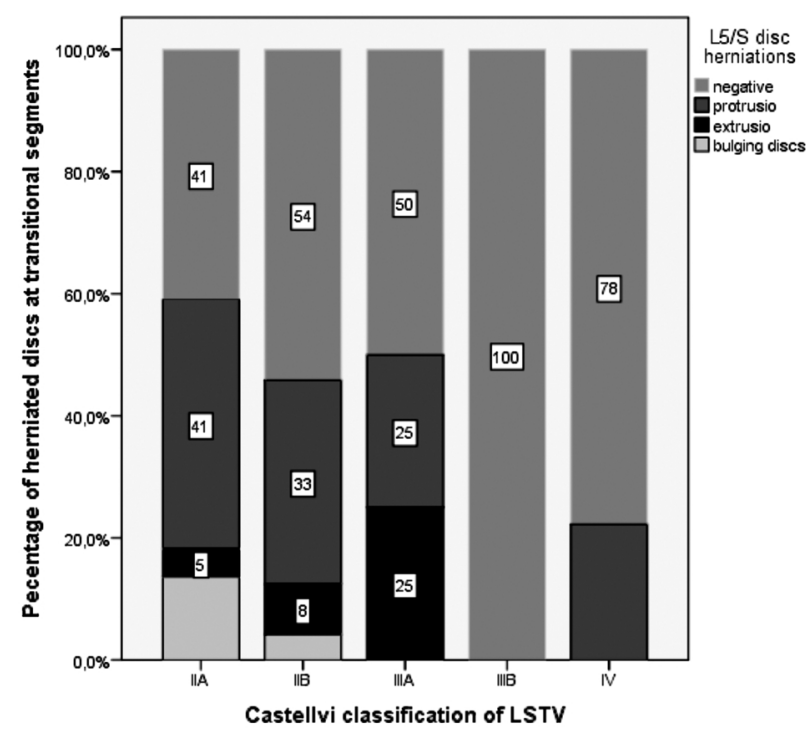

unilateral osseus connection LSTV subtype vs no disc herniations for bilateral osseus connection LSTV subtype) at the transitional level.

The number of disc herniations at the adjacent cephalad segment was lower $(27 \%$ disc herniations in patients with LSTV type IIA and $38 \%$ disc herniations in patients with LSTV type IIB). Large disc herniations (extrusions) were most frequently observed at the adjacent cephalad segment in patients with LSTV type II (25.8\% extrusions in patients with LSTV type II). At the adjacent cephalad level, higher prevalence of disc herniations was observed in bilateral articulated connection LSTV subtypes ( $38 \%$ vs $27 \%$ ) and in bilateral osseus connection LSTV subtypes (50\% disc herniati-

Figure 4. Disc herniations at the adjacent cephalad segment in different types of lumbosacral transitional vertebra (LSTV Castellvi classification)

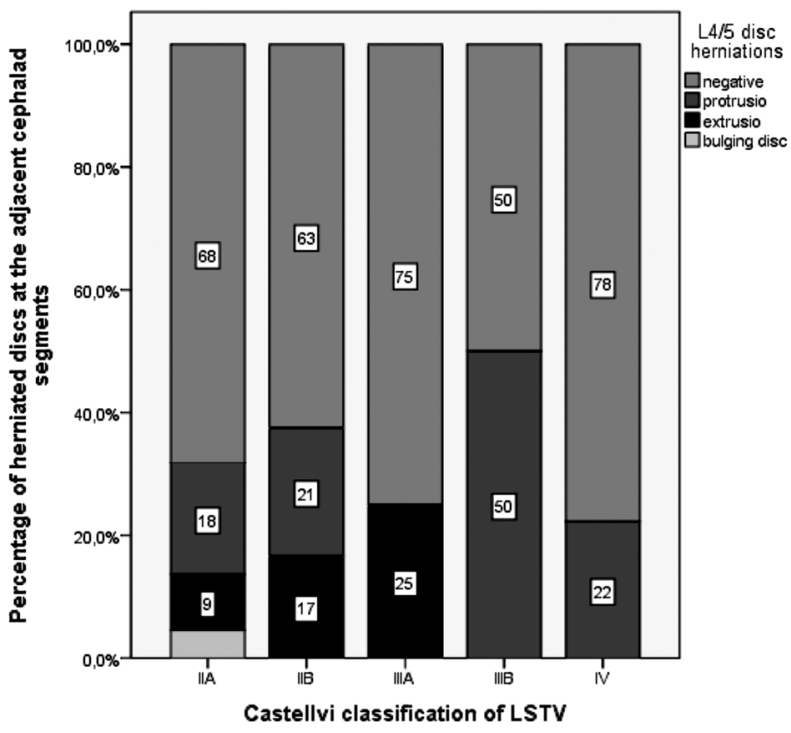

ons for bilateral osseus connection LSTV subtype vs $25 \%$ disc herniations for unilateral osseus connection LSTV subtype) (Figure 4).

\section{DISCUSSION}

The prevalence of LSTV in the literature ranges between $4 \%$ and $36 \%$ (2). Castellvi et al. reported a $30 \%$ prevalence in back pain population. The greatest number of patients in their study had LSTV type II (3). They found a prevalence rate of $31.5 \%$ in back pain population and determined the occurrence rate for each subtype of the Castellvi LSTV radiographic classification system. Our study reported Castellvi type II as the most common type of LSTV. Hughes and Saifuddin (11) reported LSTV prevalence rate of $13.4 \%$ in 500 subjects of general population. Secer et al. (12) presented anoccurrence rate of $4.5 \% \mathrm{LSTV}$ in young subjects with neurologic deficit and low back pain. Hsieh et al. (13) reported a low prevalence of LSTV of 5.9\%, while Delport (14) observed a prevalence rate of 30\%. Apazidis et al. (15) examined 211 subjects and found 75 positive for transitional lumbosacral vertebra. They used kidney-urinary bladder radiographs and reported a prevalence of $35.6 \%$ in the American general population.

The relationship of LSTV and back pain, disc disease, stenosis and other degenerative changes has been well documented in symptomatic patients (16). Our study evaluated the relationship between the specific types of lumbosacral transitional vertebra and degeneration at the transitional level and the adjacent cephalad level. According to our results there was a higher prevalence of severe disc degenerative changes in the adjacent cephalad level than at the transitional levels, dominantly in the LSTV types III and IV. There is a protective effect of the lumbosacral transition on the discs at the transitional levels. This is evident in LSTV type III, where the osseus bridging at the transitional level preserve the discs at this level from disc degeneration and transfer the stress of the spine during movements at the cephalad adjacent mobile levels. Unilaterally located subtypes of LSTV at the transitional level showed a higher prevalence of severe disc degenerative changes in our study. Unilaterally located subtypes of LSTV alter the biomechanics of the spine more expressed than bilaterally located subtypes of LSTV. In general, limited number of MRI studies analyzed the subgroups of LSTV and the sample sizes in these studies were usually small $(17,18)$, although LSTV is a high prevalent spine congenital anomaly especially in back pain population. Annular tears as a sign of early disc degenerative changes were predominantly evaluated at the transitional level in unilateral osseus bridging LSTV subtype. According to the mean age of our sample early 
disc degeneration in some individuals might be masked with age related disc degenerative changes. Higher prevalence of disc herniations was evaluated at the transitional level in articular bridging LSTV type. Also, higher prevalence of disc herniations was characteristic for unilateral subtypes and combined type of LSTV, which confirms the thesis of more excessive transfer of stress on the spine mobile segments in unilaterally and combined types of LSTV. Disc herniations were less frequent findings at cephalad adjacent segments, although high prevalence of large extrusions was notified at cephalad adjacent segments in patients with articular bridging LSTV type.

A limitation of our study might be that the examined sample do not represent asymptomatic population. However, it has been accepted that LSTV contribute to low back pain $(7,8)$. Previously published studies have also reported interreader agreement using Phirmann classificationof disc degeneration (10).

\section{CONCLUSION}

Compact osseus connection (osseus bridging vs articular bridging) of the lumboscral transitional vertebra to the sacrum protects the disc at the transitional level and produces greater stress to adjacent cephalad segment. Bilateral osseus bridging seems to be most protective to the disc at the transitional level, although this type of LSTV produces greater stress to the adjacent cephalad level. Unilateral or asymmetric articulated or osseus connection of the lumboscral transitional vertebra to the sacrum produces greater stress to the disc at the transitional level compared to the bilateral or symmetric articulated and osseus connection.
Abbreviations
LSTV - lumbosacral transitional vertebra
TP — transverse process

\title{
Sažetak
}

\section{LUMBOSAKRALNI TRANZICIONI ANATOMSKI TIPOVI I DEGENERATIVNE PROMENE DISKA}

\author{
Chabukovska Radulovska Jasminka, ${ }^{1}$ Matveeva Niki, ${ }^{2}$ Poposka Anastasika ${ }^{3}$ \\ ${ }^{1}$ University Clinic of Surgery "St. Naum Ohridski” Skopje, R Macedonia \\ ${ }^{2}$ University "St Cyril and Methodius", Medical Faculty, Institute of Anatomy, Skopje, R Macedonia \\ ${ }^{3}$ University Clinic of Orthopaedics Skopje, R Macedonia
}

Uvod i cilj: Odnos između prisustva prelaznog lumbosakralnog pršljena (LSTV) i degenerativnih promena diska je nejasan. Cilj ove studije je da ispita odnos između različitih tipova LSTV i degenerativnih promena diska u prelaznom i susednom proksimalnom segmentu.

Materijal i metode: 63 pacijenta (prosečne godine starosti 51,48 $\pm 13,51$ ) od 200 odraslih sa bolom u donjem delu leđa koji su podvrgnuti MRI pregledu lumbosakralne kičme, i kod kojih je nađen pozitivan LSTV, uključeni su u studiju. Rascepi prstena, degeneracija diska prema Phirmannovoj klasifikaciji i hernijacije diska su evaluirani i gradirani na prelazni i susedni proksimalni nivo.

Rezultati: Težina degeneracije diska u prelaznom i susednom proksimalnom nivou korelira sa tipom LSTV. Teške degenerativne promene diska su češće kod zglobno povezujućih i mešovitih LSTV tipova u prelaznom nivou, i kod kostno povezujućih LSTV tipova u susednom višem nivou. Ove promene su bile češće kod jednostranog zglobno povezujućeg LSTV subtipa ( $64 \%$ vs $54 \%$ ); kod jednostranog kostno povezujućeg LSTV subtipa (25\% vs nijedan pacijent) u prelaznom nivou, i kod bilateralnog kostno povezujućeg LSTV subtipa (100\% vs 50\%) na susednom višem nivou. Visoka prevalenca hernijacije diska je nađena kod jednostranih zglobno povezujućih LSTV tipova, kao i kod jednostranih kostno povezujućih LSTV tipova u prelaznom nivou i susednom proksimalnom nivou. $\mathrm{Na}$ susednom višem nivou veća prevalence hernijacije diska je nađena kod bilateralnog zglobno povezujućeg LSTV subtipa (38\% vs $27 \%$ ) i bilateralnog kostno povezujućeg LSTV subtipa ( $50 \%$ vs $25 \%$ ).

Zaključak: Kompaktna međukostna veza lumbosakralnog prelaznog pršljena sa sakrumom štiti disk na prelaznom nivou i izaziva veći stres na susednom proksimalnom nivou. Bilateralno kostno premošćavanje izgleda da pruža veću zaštitu diska na prelaznom nivou, ali ovaj tip LSTV stvara veći stres na susednom višem nivou.

Ključne reči: lumbosakralne anomalije; lumbosakralni prelazni pršljenovi; degeneracija diska. 


\section{REFERENCES}

1. Konin GP, Walz DM. Lumbosacral transitional vertebrae: classification, imaging findings, and clinical relevance. AJNR Am J Neuroradiol. 2010; 31(10): 1778-86.

2. Bron JL, van Royen BJ, Wuisman PI. The clinical significance of lumbosacral transitional anomalies. ActaOrthop Belg. 2007; 73(6): 687-95.

3. Castellvi AE, Goldstein LA, Chan DP. Lumbosacral transitional vertebra and their relationship with lumbar extradural defects. Spine (Philla Pa 1976). 1984;9(5):493-5.

4. Luoma K, Vehmas T,Raininko R, Luukkonen R, Riihimäki H. Lumbosacral transitional vertebra: relation to disc degeneration and low back pain. Spine (Philla Pa 1976). 2004; 29(2):200-5.

5. Aihara T, Takahashi K, Ogasawara A, Itadera E, Ono Y, Moriya $\mathrm{H}$. Intervertebral disc degeneration associated with lumbosacral transitional vertebrae: a clinical and anatomical study. J Bone Joint Surg Br. 2005; 87(5): 687-91.

6. Quinlan JF, Duke D, Eustace S. Bertolotti's syndrome. A cause of back pain in young people. J Bone Joint Surg Br. 2006; 88(9): 1183-6.

7. Brault JS, Smith J, Currier BL. Partial lumbosacral transitional vertebra resection for contralateral facetogenic pain. Spine (Philla Pa 1976); 26(2): 226-9.

8. Nardo L, Alizai H, Virayavanich W, et al. Lumbosacral transitional vertebrae: association with low back pain. Radiology. 2012; 265(2): 497-503.

9. Albert HB, Briggs AM, Kent P, Byrhagen A, Hansen C, Kjaergaard K. 1. The prevalence of MRI-defined spinal pathoanatomies and their association with modic changes in individu- als seeking care for low back pain. Eur Spine J. 2011; 20(8): 1335-62.

10. Pfirrmann CW, Metzdorf A, ZanettiM, Hodler J, Boos N. Magnetic resonance classification of lumbar intervertebral disc degeneration. Spine. 2001; 26(17): 1873-8.

11. Hughes RJ, Saifuddin A. Numbering of lumbosacral transitional vertebrae on MRI: role of the iliolumbar ligaments. AJR Am J Roentgenol. 2006; 187(1): W59-65.

12. Secer M, Muradov JM, Dalgic A. Evaluation of congenital lumbosacral malformations and neurological findings in patients with low back pain. Turk Neurosurg.2009; 19(2): 145-8.

13. Hsieh CY, Vanderford JD, Moreau SR, Prong T. Lumbosacral transitional segments: classification, prevalence, and effect on disc height. J Manipulative Physiol Ther. 2000; 23(7): 483-9.

14. Delport EG, Cucuzzella TR, Kim N, Marley J, Pruitt C, Delport AG. Lumbosacral transitional vertebra: incidence in a consecutive patient series. Pain Physician. 2006; 9(1): 53-6.

15. Apazidis A, Ricart PA, Diefenbach PC, Spivak JM. The prevalence of transitional vertebrae in the lumbar spine. Spine J. 2011; 11(9): 858-62.

16. Konin GP, Walz DM. Lumbosacral transitional vertebrae: classification, imaging findings, and clinical relevance. AJNR Am J Neuroradiol. 2010; 31(10): 1778-86.

17. Quinlan JF, Duke D, Eustace S. Bertolotti's syndrome: a cause of back pain in young people. J Bone Joint Surg Br. 2006; 88(9): 1183-6.

18. Taskaynatan MA, Izci Y, Ozgul A, Hazneci B, Dursun $\mathrm{H}$, Kalyon TA. Clinical significance of congenital lumbosacral malformations in young male population with prolonged low back pain. Spine (Philla Pa 1976). 2005; 30(8):E210-3.

\section{Correspondence to/Autor za korespondenciju}

Jasminka Chabukovska-Radulovska

11 Oktomvri 53, 1000 Skopje, R. Macedonia

Tel. 0038975228853

e-mail: j.cabukovska@yahoo.com 